\title{
Orange-fleshed sweet potato grown in Viet Nam as a potential source for making noodles
}

\author{
*Thuy, N.M., Chi, N.T.D., Huyen, T.H.B. and Tai, N.V. \\ Department of Food Technology, College of Agriculture, Can Tho University, Viet Nam
}

\begin{abstract}
Article history:
Received: 21 November 2019

Received in revised form: 4 January 2020

Accepted: 5 January 2020

Available Online: 17 January 2020
\end{abstract}

\section{Keywords:}

Cooking quality,

Noodles,

Orange-fleshed sweet potato, Physicochemical properties, Wheat flour

\section{DOI:}

https://doi.org/10.26656/fr.2017.4(3).390

\begin{abstract}
Orange-fleshed sweet potato (OFSP) noodles were created by replacing a portion of the wheat flour with OFSP flour in a formulation. This study was performed to identify the physical and chemical characteristics as well as sensorial attributes of noodles prepared from OFSP with some flours (wheat flour and semolina). The addition of xanthan gum and incubation time was examined. Instrumental analyses of noodles (cooking loss, volume increase, rehydration ratio, structure and microstructure) were carried out to assess the impact of experimental factors. The obtained results revealed that noodles made with more OFSP flour had a more yellow color than those with less OFSP flour. The mixture of OFSP and wheat flour in the formula F2 (the percent of OFSP $18.79 \%$ and wheat flour $28.18 \%$ ) produced noodles with high quality and was the most favorable in appearance, taste, texture, and acceptability among the four formulas. Cooking weight and volume were increased from 164.89 to $174.12 \%$ and from 184.74 to $194.81 \%$, respectively when semolina was added to the formula. The supplemental semolina $10.57 \%$, xanthan gum of $2 \%$ and the incubation time 30 mins were obtained to enhance dough binding properties. The results suggest that OFSP flour could be replaced up to $40 \%$ wheat flour for noodles to improve the nutritional value (i.e. increased b-carotene) and might be acceptable to consumers with health food.
\end{abstract}

\section{Introduction}

Sweet potato (Ipomoea batatas L.) is one of the most traditional root crops in many countries. Sweet potatoes are sweet, starchy root vegetables with a variety of sizes and colors, including orange, white, and purple which provide several health benefits. The OFSP variety rich in beta-carotene is considered as a very cheap source of vitamins (Mitra, 2012) and fiber. The sweet potato varieties are rich in protein, carbohydrate, polyphenol, carotenoids and low in fat, this could be a good source of dietary antioxidants for preventing free radical damage, which leads to chronic diseases and to prevent vitamin A malnutrition (Haskell et al., 2004; Alam et al., 2016).

In Viet Nam, sweet potato is the third traditional food crop after rice and corn and second in economic value after potatoes. Sweet potatoes are grown throughout the country. The area of sweet potato cultivation across the country is 175.5 thousand hectares with an output of 1437.6 tons (GSO, 2009). In Binh Tan district, Vinh Long province, which is considered the "kingdom" of sweet potatoes of the Mekong Delta, farmers are struggling to stand down when the price of sweet potatoes is falling badly, mainly due to being traded and consumed in fresh form. Their superior nutritional composition makes them a better alternative than synthetic food colorants, give them high potential as value-added and functional food products (BovellBenjamin, 2007).

In general, noodle is prepared from wheat flour. However, some studies reported that the use of wheat flour could partly be substituted with other flours. Senthil et al. (2002) blended wheat flour and defatted soy flour. The fortification of durum wheat semolina was done by the combination of chickpea flour and defatted soy flour at different levels (Bashir et al., 2012). Starch noodles differ in their texture and quality from Asian or European countries, are made from wheat flour or semolina ( $\mathrm{Fu}, 2008)$. Starch-based noodles have been attempted from legume starches such as broad bean or cowpea, corn starch or tuber starches such as potato, sweet potato and cassava (Kim et al., 1996; Collado and Cork, 1997; Singh et al., 2002). The use of sweet potato flour is more economical and practical. It also improves more health benefits. Utomo and Yulifianti (2012) reported that noodle containing $40 \%$ of purple-fleshed 
sweet potato paste has acceptable physical, chemical and sensorial performances. Although the usefulness of orange-fleshed sweet potato has been documented, its utilization in Viet Nam is still limited. Sweet potatoes are now abundant due to low prices at the time of the crop and due to unsatisfactory shape, size or physical damage. Therefore, taking advantage of this nutrient-rich material and applying processing techniques to reduce the postharvest losses, generate new market opportunities for new and added-value products should be considered. This study was aimed at evaluating noodles produced using a composite mixture of orange-fleshed sweet potato, wheat flour and semolina. The amount of additional ingredient (xanthan gum) and incubation time were determined. It was hypothesized that acceptable product quality and an improved nutritional value could be maintained in noodles by replacing a portion of wheat flour with OFSP flour without unchanged the conventional processing operation.

\section{Materials and methods}

\subsection{Preparation of orange-fleshed sweet potato flour}

The OFSP (KB1 variety) was obtained in Vinh Long province, Viet Nam. They were sorted, washed, peeled and sliced into thin pieces (about $2 \mathrm{~mm}$ ). The sliced sweet potatoes were blanched by steaming at $100^{\circ} \mathrm{C}$ for 3 mins to prevent browning reactions. The blanched slices were dried in a hot air oven at $60^{\circ} \mathrm{C}$ until the moisture content of $12 \%$ was achieved. Subsequently, the dried sliced sweet potatoes were ground, sieved (flour should pass through a $212 \mu \mathrm{m}$ sieve - US Standard Mesh No. 70) and packaged inside a plastic container.

\subsection{Formulation of mixed flours}

All the ingredients were mixed into 4 formulas according to the specified ratio for the processing of noodles (Table 1 ). The total components are $100 \%$. The formulation was adjusted to include OFSP flour at 16.44, $18.79,21.14$ and $23.49 \%$, the wheat flour at 30.53 , $28.18,25.83,23.49 \%$ of the total. The control sample in this study was formulated with whole wheat flour
(46.97\%) without OFSP flour. This experiment was conducted to further improve dough functionality. Each recipe was prepared with the weight of calculated ingredients. Put all in equipment and stirred for 5 mins, then incubated for 30 mins. After tempering time, noodles were created by extruding the dough through a PHILIPS Pasta Maker. Noodles were cut into a strip (25 $\mathrm{cm})$ and then dried (2.5-3 mins) at $60^{\circ} \mathrm{C}$ until the moisture content reached $6-8 \%$. The quality of the finished product was analyzed.

\subsection{Effect of semolina}

Bobs Red Mill Semolina Flour (24 Oz/bag) was used for this experiment. From the selected formula, change the semolina content of 35,40 and $45 \mathrm{~g}$ (the weight of each batch of experiments was $425.8 \mathrm{~g}$ ), respectively. In this case, the missing of $5 \mathrm{~g}$ in the recipe (if $35 \mathrm{~g}$ of semolina used) or excessive of $5 \mathrm{~g}$ (45 $\mathrm{g}$ semolina used) was replaced by increasing or decreasing accordingly by $5 \mathrm{~g}$ of wheat flour, so that the total weight of the recipe is always equal to $425.8 \mathrm{~g}$ (as mentioned in Table 1).

\subsection{Effect of xanthan gum concentration and incubation time on the quality of product}

Since the addition of xanthan gum improved the functional and textural properties of sweet potato dough, additional experiments were conducted to determine specific effects of xanthan gum levels $(1.5,2.0,2.5 \%)$ and tempering time (30 and 45 mins) on the quality of the sweet potato noodles. Samples were prepared with the selected formula from the previous experiment. Noodles were extruded as described above.

\subsection{Determination of nutritional and physicochemical properties of composite flour and their noodle product}

\subsubsection{Determination of moisture content}

Each sample of $2 \mathrm{~g}$ was weighed into the crucibles and dried at $105^{\circ} \mathrm{C}$ until a constant weight was obtained. This procedure was carried out for all the samples. The moisture content was calculated as follows in equation 1.

$\%$ Moisture content $=\left[\left(\mathrm{W}_{2}-\mathrm{W}_{3}\right) /\left(\mathrm{W}_{2}-\mathrm{W}_{1}\right)\right] \times 100$

Table 1. Formulation of orange-fleshed sweet potato noodle

\begin{tabular}{lcccccccccc}
\hline Ingredients & F0 $(\mathrm{g})$ & $\mathrm{F} 0(\%)$ & $\mathrm{F} 1(\mathrm{~g})$ & $\mathrm{F} 1(\%)$ & $\mathrm{F} 2(\mathrm{~g})$ & $\mathrm{F} 2(\%)$ & $\mathrm{F} 3(\mathrm{~g})$ & $\mathrm{F} 3(\%)$ & $\mathrm{F} 4(\mathrm{~g})$ & $\mathrm{F} 4(\%)$ \\
\hline OFSP flour & 0 & 0 & 70 & 16.44 & 80 & 18.79 & 90 & 21.14 & 100 & 23.49 \\
Wheat flour & 200 & 46.97 & 130 & 30.53 & 120 & 28.18 & 110 & 25.83 & 100 & 23.49 \\
Semolina & 40 & 9.39 & 40 & 9.39 & 40 & 9.39 & 40 & 9.39 & 40 & 9.39 \\
Sweet potato starch & 50 & 11.74 & 50 & 11.74 & 50 & 11.74 & 50 & 11.74 & 50 & 11.74 \\
Salt & 2 & 0.47 & 2 & 0.47 & 2 & 0.47 & 2 & 0.47 & 2 & 0.47 \\
Egg & 65 & 15.27 & 65 & 15.27 & 65 & 15.27 & 65 & 15.27 & 65 & 15.27 \\
Water & 63 & 14.8 & 63 & 14.8 & 63 & 14.8 & 63 & 14.8 & 63 & 14.8 \\
Xanthan gum & 5.8 & 1.36 & 5.8 & 1.36 & 5.8 & 1.36 & 5.8 & 1.36 & 5.8 & 1.36 \\
Total & 425.8 & 100 & 425.8 & 100 & 425.8 & 100 & 425.8 & 100 & 425.8 & 100 \\
\hline
\end{tabular}


Where $\mathrm{W}_{1}$ is the initial weight of the empty crucible; $\mathrm{W}_{2}$ is the weight of crucible + sample before drying; and $\mathrm{W}_{3}$ is the weight of crucible + sample after drying.

\subsubsection{Determination of protein content}

Protein $(\mathrm{N} \times 6.25)$ was determined according to the AOAC (1980).

\subsubsection{Determination of total carbohydrate}

The total carbohydrate content was determined according to the method of McCseady (1970) and Dubois et al. (1956). An amount of $0.2 \mathrm{~g}$ of the sample was accurately weighed into different test tubes in triplicates; $0.8 \mathrm{~mL}$ of distilled water was then added. Phenol 5\% $(0.5 \mathrm{~mL})$ was added to each test tube and mixed, and $2.5 \mathrm{~mL}$ of concentrated sulfuric acid added for color development. The tubers were allowed to cool, and the absorbance was measured using the spectrophotometer (V-5000 Visible, China) at $490 \mathrm{~nm}$. For the standard curve, $100 \mathrm{mg} / \mathrm{mL}$ of glucose was prepared. Serial dilution of glucose was prepared, and color development monitored at $490 \mathrm{~nm}$ for the different glucose concentrations. One $\mathrm{mL}$ of distilled water was used as blank. A standard curve was plotted and used to calculate the total carbohydrate concentration in the samples.

\subsubsection{Determination of $\beta$-carotene}

The $\beta$-carotene content was determined according to the method of Fikselová et al. (2008). Briefly, $25 \mathrm{~g}$ of samples were added to $100 \mathrm{~g}$ of 2-propanol. Samples were extracted at $60^{\circ} \mathrm{C}$ in a water bath, shaken after every 10 mins, and after every hour of extraction $5 \mathrm{~mL}$ sample was taken and mixed with $20 \mathrm{~mL}$ petroleum ether. Water was added for the separation of phases, and after the separation, the petroleum-ether-carotenoid phase was made up to the volume of $50 \mathrm{~mL}$. The content of $\beta$-carotene in the petroleum-ether (Sigma-Aldrich) extract was determined spectrophotometrically, the absorbance was measured at the wavelength of $450 \mathrm{~mm}$ using the spectrophotometer (V-5000 Visible, China). The concentration of carotenes expressed as $\beta$-carotene was calculated using the response factors as follows (equation 2).

$$
\beta \text { - carotene content }(\mu \mathrm{g} / \mathrm{g})=\frac{\mathrm{A} \times \mathrm{d} \times \mathrm{V}}{\mathrm{E}_{1 \mathrm{~cm}}^{1 \%} \times \mathrm{w}}
$$

Where $\mathrm{A}$ is absorbance; $\mathrm{d}$ is dilution $(\mathrm{g} / \mathrm{mL}) ; E_{1 \mathrm{~cm}}^{1 \%}$ is the absorption coefficient of $\beta$-carotene in petroleum ether (2592); $\mathrm{w}$ is the weight of sample (g); and V is the total volume of extract $(\mathrm{mL})$. Multiply by 100 to give the carotene content in $\mu \mathrm{g} / 100 \mathrm{~g}$.

\subsubsection{Dry matter content determination}

Sample (20 g) was sliced into small sizes, weighed, transferred into the container and drying at $105^{\circ} \mathrm{C}$ for 24 hrs (Teye et al., 2011). Dry matter content (DM) in the sample was calculated (equation 3) using the following equation.

$$
\mathrm{DM}(\%)=\frac{\mathrm{M} 2 \times 100}{\mathrm{M} 1}
$$

Where M1 is the weight of the initial (wet) sample and M2 the weight after drying.

\subsubsection{Hardness testing}

Texture attributes were analyzed with a Brookfield CT3 Texture Analyzer equipped with a 1,500 g load cell and software version 1.8 (Brookfield Engineering Laboratories, Middleboro, MA, USA) using the following settings: text type TPA (texture profile analysis); test speed: $2 \mathrm{~mm} / \mathrm{g}$; target type: Stop @ Load; target value: $1000 \mathrm{~g}$ and trigger force: $5 \mathrm{~g}$. Five randomly picked cooked noodle strands were placed perpendicular to the long edge of the probe on the fixture base table. A wedge-shaped probe (part number TAPFS) was used for texture profile analysis.

\subsubsection{Color measurement}

The color of uncooked and dried noodles enriched with OFSP and control sample was measured on the Hunter scale for $\mathrm{L}$, $\mathrm{a}$, and $\mathrm{b}$ using a Minolta chroma meter (CR-400, Konica Minolta, Tokyo, Japan). A white standard plate was used to calibrate the colorimeter: " $\mathrm{L}$ values" describe black to white $(0-100)$; "a values" describe redness (positive) and greenness (negative); and "b values" describe the yellowness (positive) and blueness (negative). At least five measurements were carried out on each sample.

\subsubsection{Scanning electron microscopy (SEM)}

Dried uncooked/cooked noodles (as the method described earlier) were cut using a razor blade and the sample was mounted onto brass stubs using double-sided carbon conductive adhesive tape. A gold coating (0.5 nanometers thick) was then applied under 8-9 pascal vacuum. Bulk samples were examined at $15 \mathrm{kV}$, the sample distance to the $7 \mathrm{~cm}$ ejection glass, $230 \mathrm{x}$ magnification using a JEOL model J550 scanning electron microscope (Japan).

\subsubsection{Cooking quality}

Cooking loss (\%), rehydration rate (weight increase) (\%) and volume increase (\%) were performed to determine the cooking quality. A $50 \mathrm{~g}$ of noodles were placed into $500 \mathrm{~mL}$ of boiling water. The optimum 
cooking time was established by boiling the noodles in distilled water until the white center core of the noodles strand disappears, indicating that the starch at the center has gelatinized. After different interval time (2.5, 3 and 3.5 mins), samples were removed, washed with distilled water and drained for 2 mins. Cooked noodles were collected by separating from cook water with a strainer. The collected cook water was dried in an oven at $103^{\circ} \mathrm{C}$ for cooking loss (CL) estimation (equation 4) (Wang and Ratnayake, 2015). Cooked noodles were dried in the oven at $103^{\circ} \mathrm{C}$ for $20 \mathrm{~h}$ to estimate the rehydration ratio (RR) (equation 5) (Kamolchote et al., 2010). The volume increase (\%) was also estimated (equation 6).

$$
\begin{aligned}
& \text { CL }(\%)=\frac{\text { Weight of residue from cooking water }(\mathrm{g})}{\text { Weight of noodle sample }(\mathrm{g})} \times 100 \\
& \mathrm{RR}(\%)=\frac{\mathrm{WCN}(\mathrm{g})-\mathrm{OWN}(\mathrm{g})}{\mathrm{OWN}(\mathrm{g})} \times 100
\end{aligned}
$$

Where WCN is the weight of cooked noodles and OWN is the original weight of noodles.

Volume increase $(\%)=\frac{\text { Volume of cooked pasta-Volume of uncooked pasta }}{\text { Volume of uncooked pasta }} \times 100(6)$

\subsection{Statistical analysis}

The experiments were performed with three replicates. Descriptive statistics were performed for all variables. One-way analysis of variance (ANOVA) was performed to test the differences among experiments. Differences at $p<0.05$ were considered to be statistically significant. Experimental results were expressed as the mean \pm standard deviation (SD).

\section{Results and discussion}

\subsection{The chemical composition of OFSP}

The chemical composition of OFSP can be seen in Table 2. It was observed that the moisture content of the sweet potato was about $74.7 \pm 0.35 \%$. The obtained results are similar to the range of values (63.1 to $83.8 \%$ ) reported by Osundahunsi et al. (2003) and $74.4 \%$ by Aina et al. (2009). The dry matter and starch content of $25.3 \%$ and $14.17 \%$ were observed, respectively. It was recorded $\beta$-carotene content of the orange-flesh sweet potato varies about $4.41 \pm 0.2 \mathrm{mg} / 100 \mathrm{~g}$. The present study is more or less in agreement with the others. Rahman et al. (2013) reported that the different varieties of OFSP contained $\beta$-carotene content from 1.17 to
$11.03 \mathrm{mg} / 100 \mathrm{~g} \mathrm{FW}$. The variety of Daulatpuri sweet potato contained the dry matter of $33.5 \%$ was reported by Jahan and Siddique (2001). $\beta$-carotene content was reported in the ranges of 4.1 to $14.4 \mathrm{mg} / 100 \mathrm{~g}$ (Roy et al., 2012). The protein content of orange-flesh sweet potato was about $1.60 \pm 0.05 \%$. This is in similar to the obtained results of other studies. The protein content of the selected OFSP varieties ranged from $1.91 \pm 0.01 \%$ to $5.83 \pm 0.30 \%$ (Alam et al., 2016). The small variations in the quality among the OFSP can be due to the differences in the genetic composition and cultivation practices.

Table 2. The chemical composition of orange-flesh sweet potato

\begin{tabular}{lc}
\hline \multicolumn{1}{c}{ Chemical composition } & Content \\
\hline Moisture content $(\%)$ & $74.70 \pm 0.35$ \\
Dry matter $(\%)$ & $25.3 \pm 0.10$ \\
Starch content $(\%)$ & $14.17 \pm 1,36$ \\
Protein $(\%)$ & $1.60 \pm 0.05$ \\
$\beta$-carotene $(\mathrm{mg} / 100 \mathrm{~g})$ & $4.41 \pm 0.20$ \\
\hline
\end{tabular}

\subsection{Effect of ratio of OFSP flour and wheat flour}

\subsubsection{The physical characteristics of OFSP noodles \\ 3.2.1.1 Color}

Color is one of the most important quality properties for the acceptability of food. It has a direct effect on consumers' perceptions. After mixing different ratios of flour, noodles were made and dried at a constant temperature of $60^{\circ} \mathrm{C}$ to moisture less than $8 \%$. The color of noodles is shown in Table 3. By replacing a part of wheat flour with OFSP flour, the noodles were more yellow, the brightness also increased significantly $(\mathrm{P}<0.05)$.The brightest samples were obtained in the OFSP flour addition, expressed as an increase of $\mathrm{L}^{*}$ values (from 65.50 for reference sample to 66.2 for the sample with $16.44 \%$ OFSP flour), with more pronounced differences for samples produced with higher percent of OFSP flour (18.79 to $23.49 \%$ ) (Figure 1). The $b^{*}$ values increased proportionally to OFSP flour addition, indicating an increase of yellow component. These results were consistent with the report of Taneya et al. (2014), they concluded that increasing the proportion of added sweet potato flour from $10 \%$ to $30 \%$ in noodles can increase the $L^{*}$ value. Ginting and Yulifianti (2015) reported that $40 \%$ of sweet potato flour was added to the

\begin{tabular}{|c|c|c|c|c|}
\hline \multirow{2}{*}{ Formula } & \multirow{2}{*}{ Ratio of OFSP (\%): WF (\%) } & \multicolumn{2}{|c|}{ Color } & \multirow{2}{*}{ Hardness ( $\mathrm{g}$ force) } \\
\hline & & $\mathrm{L}^{*}$ & $\mathrm{~b}^{*}$ & \\
\hline F0 & $00: 47.0$ & $65.50^{\mathrm{a}}$ & $5.00^{\mathrm{a}}$ & $85.5 \pm 0.69$ \\
\hline $\mathrm{F} 1$ & $16.44: 30.54$ & $66.20^{\mathrm{b}}$ & $6.20^{\mathrm{b}}$ & $70.3 \pm 1.53$ \\
\hline $\mathrm{F} 2$ & 18.79: 28.19 & $68.98^{\mathrm{c}}$ & $7.06^{\mathrm{c}}$ & $67.0 \pm 2.00$ \\
\hline F3 & $21.14: 25.84$ & $69.05^{\mathrm{d}}$ & $7.86^{\mathrm{d}}$ & $62.7 \pm 0.58$ \\
\hline $\mathrm{F} 4$ & $23.49: 23.49$ & $69.22^{\mathrm{d}}$ & $7.79^{d}$ & $58.3 \pm 1.53$ \\
\hline
\end{tabular}

Table 3. The color and hardness of noodles with different ratios of OFSP and wheat flour (WF)

Values with different superscripts are significantly different $(\mathrm{P}<0.05)$. L*, $\mathrm{a}^{*}, \mathrm{~b}^{*}$ of the reference sample $(100 \%$ of wheat flour) are $65.5,-4,5$, respectively 
noodles for a nice bright color and good sensory perception. Noodles supplemented with OFSP powder also showed a brighter color than the sweet potato-free sample or only sweet cream-colored sweet potato (Krishnan et al., 2012). The value of $\mathrm{a}^{*}$ has no significant difference between mixing ratios and is close to that of the reference sample ( $a^{*}$ is -4$)$. The values $L^{*}$ and $b^{*}$ increased in the F1 (66.20 and 6.20) and F2 (68.98 and 7.06) and there was no significant difference between the mixing ratios of F3 and F4 formulas.

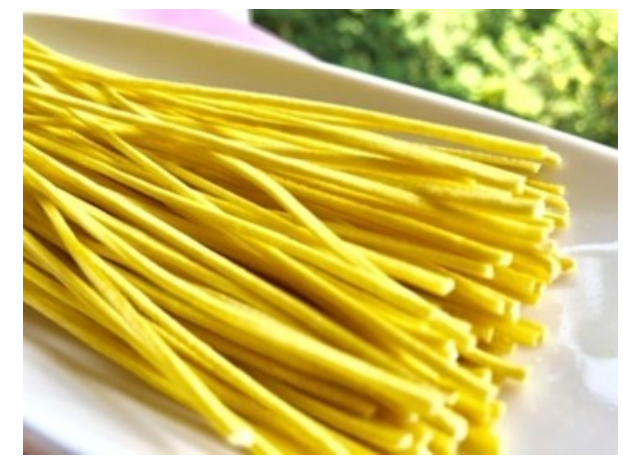

Figure 1. The color of noodles from formula F2

\subsubsection{Structure}

The obtained results showed that the strength of dried noodles made from a higher content of wheat flour is stronger than added OFSP flour noodles. There was a significant difference in structure between the control sample ( $100 \%$ flour) and different mixing ratios of OFSP flour and wheat flour. This means that the sweet potato powder affects the structure of the sweet potato noodles. The firmness of noodles reached the highest value $(85.5 \pm 0.69 \mathrm{~g}$ force) when the mixing ratio of OFSP flour: wheat flour is $0: 46.98 \%$ (formula F0) and the lowest $(58.3 \pm 1.53 \mathrm{~g}$ force) when the mixing ratio was 23.49:23.49\% (formula F4). These results are quite consistent with the report of Collado and Corke (1996), they concluded that when increasing the rate of purple sweet potatoes added, the structure of noodles decreased. The measured firmness of noodles with mixing ratio F1
(OFSP flour: wheat flour $=16.44: 30.54 \%$ ) and F2 (OFSP flour: wheat flour $=18.79: 28.19 \%$ ) were observed in between $70.3 \pm 1.53$ and $67.0 \pm 2.00 \mathrm{~g}$ force, respectively, which showed the average values.

\subsubsection{Microstructure of dried noodles}

Scanning Electron Microscopy gives information about the size, shape and arrangement of particles in the noodle's matrix (Tudorica et al., 2002). The microscopic pictures can help analyze the appearance, texture or integrity of food products (Gorinstein et al., 2004). The analysis of the scanning electron microscopy crosssections of dried noodles made from different flours revealed that the binding forces between the protein matrix and starch granules are different. The binding force between the protein and starch of higher content of wheat flour (lower content of OFSP flour) is stronger than that of the lower content of wheat flour (higher content of OFSP flour) (Figure 2a and 2b). Small holes were apparent on the surface of the dried noodles which could permit the penetration of water into the interior of noodles during cooking. The presence of small cracks with a small number of empty spaces in noodles made with a higher content of OFSP, which suggests some lack of continuity due to the absence of gluten. Also, the graphs showed the structure of poorly agglomerated starch granules and separate granules visible in the product with a high content of OFSP flour (Figure 2c, 2d and 2e).

\subsubsection{The chemical composition of noodles}

Adding more OFSP flour increased the level of $b$ carotene and protein in the noodles. Noodles made with more OFSP flour had a more protein and $\beta$-carotene (yellow color) than those with less OFSP flour (Formula F1 to formula F4) (Table 4).

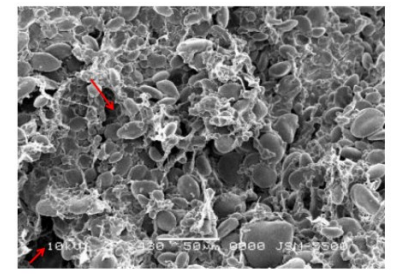

a. F0 (OFSP flour: Wheat flour $=$

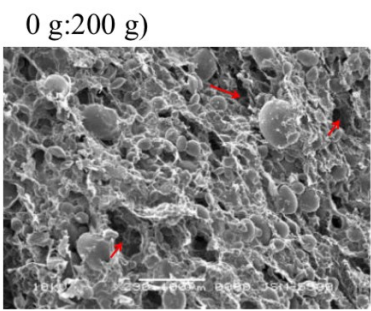

d. F3 (OFSP flour:Wheat flour $=90 \mathrm{~g}: 110 \mathrm{~g}$ )

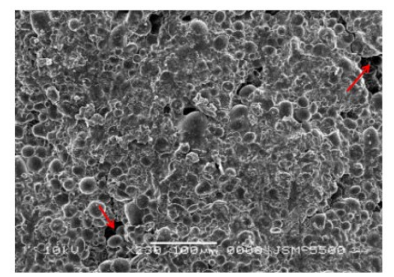

b. F1 (OFSP flour:Wheat flour = $70 \mathrm{~g}: 130 \mathrm{~g})$

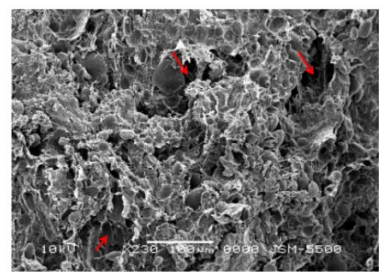

c. F2 (OFSP flour: Wheat flour $=$ $80 \mathrm{~g}: 120 \mathrm{~g})$

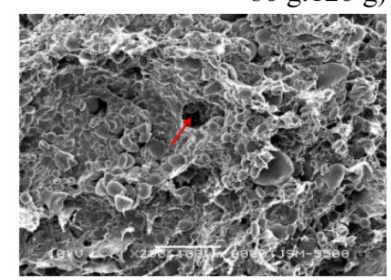

e. F4 (OFSP flour:Wheat flour $=100 \mathrm{~g}: 100 \mathrm{~g}$ )

Figure 2. Cross-section of noodles (with different OFSP: Wheat flour mixing) observed with SEM (230x magnification) 
Table 4. The chemical properties of noodles with different ratios of OFSP and wheat flour (WF)

\begin{tabular}{cccccccc}
\hline Formula & Ratio of OFSP : WF (\%) & Protein $(\%)$ & $\beta$-carotene $(\mathrm{mg} / 100 \mathrm{~g})$ & Starch $(\%)$ & Fiber (\%) & Fat (\%) & Total energy (kcal) \\
\hline F0 & $00: 47.0$ & $11.91 \pm 0.12$ & 0 & $59.23 \pm 0.35$ & $1.55 \pm 0.01$ & $1.20 \pm 0.05$ & 295.36 \\
F1 & $16.44: 30.54$ & $10.92 \pm 0.25$ & $11.21 \pm 0.31$ & $60.57 \pm 0.42$ & $1.80 \pm 0.01$ & $1.25 \pm 0.05$ & 297.21 \\
F2 & $18.79: 28.19$ & $9.54 \pm 0.52$ & $12.81 \pm 0.95$ & $61.58 \pm 0.56$ & $1.85 \pm 0.05$ & $1.28 \pm 0.08$ & 296 \\
F3 & $21.14: 25.84$ & $9.16 \pm 0.75$ & $14.42 \pm 0.68$ & $63.30 \pm 0.44$ & $1.92 \pm 0.10$ & $0.82 \pm 0.07$ & 297.22 \\
F4 & $23.49: 23.49$ & $9.27 \pm 0.51$ & $16.02 \pm 0.87$ & $63.59 \pm 0.82$ & $1.89 \pm 0.08$ & $0.90 \pm 0.10$ & 299.54 \\
\hline
\end{tabular}

Values are expressed as mean $\pm \mathrm{SD}$

\subsection{Effect of semolina}

The microstructure of noodles with the addition of different contents of semolina is shown in Figure 3. The SEM micrographs showed that widely distributed pores were formed during the process of dehydration. It was clear that noodles made with $10.57 \%$ semolina in the dough (Figure 3c) had more homogeneous and smoother appearance than others (Figure $3 \mathrm{a}$ and $3 \mathrm{~b}$ ). The sample with $8.22 \%$ addition of semolina (Figure $3 a$ ) showed large pores and size heterogeneity, revealed the interferences of semolina on the protein matrix and starch granules (Penella et al., 2008). This sample also displayed weaker structure formation inside the noodles, thereby resulting in a large number of voids. The holes and voids might cause a less compact and softer texture of the cooked noodles, which was consistent with the decrease of the noodle hardness values. It has been reported that the inner and surface structure (porosity) of the noodle strands had a great effect on the texture properties of the noodles (Barros et al., 2010).In general, the semolina in dough strengthened the cross-linking amongst gluten network, reducing hollows and voids in the noodle structure. Subsequently, the changes in the inner and surface microstructure of the noodles influenced the sensory quality of the final product. Dough strength reflected the innate gluten strength and protein content of semolina. Manthey et al. (2000) also reported a reduction in dough strength by semolina flour. They attributed the reduced dough strength to the interference in gluten formation by semolina during dough development.

\subsubsection{The cooking attributes and texture of cooked/ uncooked noodle}

Noodle supplement with OFSP flour quality could be evaluated by cooking attributes such as weight increase, cooking loss and volume increase. The weight and volume increase of noodle ranged from 164.89 to $174.12 \%$ and from 184.74 to $194.81 \%$, respectively. Addition of semolina increased the water absorption and weight and volume increase of noodles (Table 5). A further increase of semolina content slightly raised it, but with no statistical significance. These results agreed with

Table 5. Cooking quality parameters of noodles supplemented with OFSP flour

\begin{tabular}{lccc}
\hline & \multicolumn{3}{c}{ The content of semolina addition (\%) } \\
\cline { 2 - 4 } & 8.22 & 9.39 & 10.57 \\
\hline $\begin{array}{l}\text { Weight increase } \\
\text { (\%) }\end{array}$ & $164.89 \pm 1.23^{\mathrm{a}}$ & $170.23 \pm 4.32^{\mathrm{b}}$ & $174.12 \pm 2.34^{\mathrm{b}}$ \\
$\begin{array}{l}\text { Volume increase } \\
(\%)\end{array}$ & $184.74 \pm 15.71^{\mathrm{a}}$ & $187.22 \pm 10.23^{\mathrm{a}}$ & $194.81 \pm 33.64^{\mathrm{a}}$ \\
$\begin{array}{l}\text { Cooking loss } \\
(\%)\end{array}$ & $7.29 \pm 0.21^{\mathrm{a}}$ & $7.34 \pm 0.16^{\mathrm{a}}$ & $7.33 \pm 0.35^{\mathrm{a}}$ \\
\hline
\end{tabular}

Values are expressed as mean $\pm \mathrm{SD}, \mathrm{n}=3$. Means followed by different letters in a row are significantly different $(\mathrm{P}<0.05)$.

Salem et al. (2005) who explained that the increase in weight of semolina may be a result of absorbed more water.

Cooking losses are one of the basic parameters used to predict noodles cooking quality. These values indicate the amount of dry matter loss into the cooking water (Sozer et al., 2007). The results showed that cooking loss of noodle with semolina $(9.39,10.57$ and $11.74 \%)$ found to be $7.29,7.34$ and $7.33 \%$, respectively (as mentioned in Table 5). Cacak-Pietrzak et al. (1997) reported that cooking losses of different pasta types made from semolina ranged from 6 to $11 \%$. The cooking losses in all the pasta samples was below the technologically acceptable limit $(\leq 8 \%)$ (Dick and Youngs, 1998). Adding semolina with these levels did not affect the cooking losses.

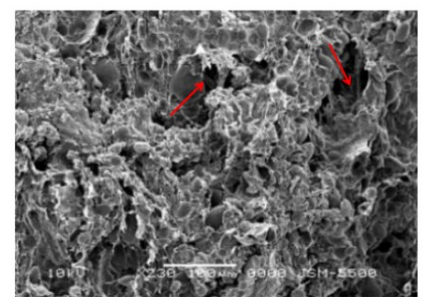

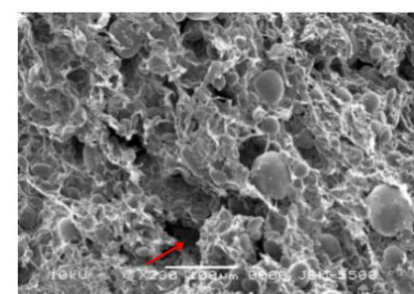

b.

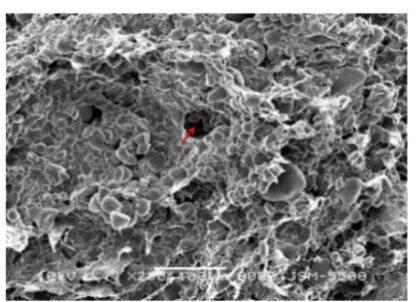

c.

Figure 3. SEM micrographs of a. $8.22 \%$, b. $9.39 \%$, c. $10.57 \%$ of semolina addition (230x magnification) 
The microstructure of the cross-section of cooked/ uncooked noodles was investigated using SEM. During the cooking process, starch undergoes a transition process, known as gelatinization, when starch gelatinized completely, and a unique network of starch and proteins are formed. The microstructure of cooked dough clearly showed that swollen starch granules were associated with gelatinization. As displayed in Figure 4, starch granules can be easily identified and are completely covered by gluten matrix in the cooked noodles. In the cooked noodles (Figure 5), swollen, hydrated, and gelatinized starch granules are fused and occupy the

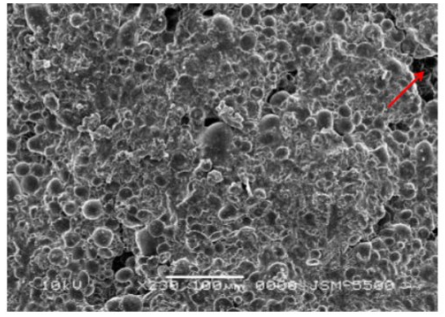

(OFSP flour: Wheat flour:SE $=70: 130: 40$ )

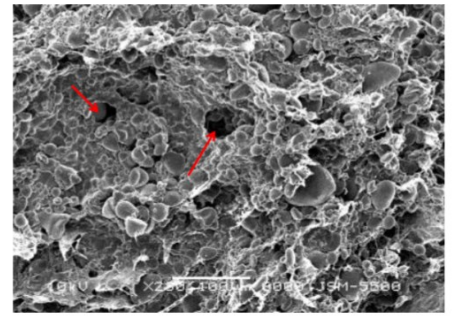

(OFSP flour:Wheat flour:SE = 115:75:45)

a. Before cooking
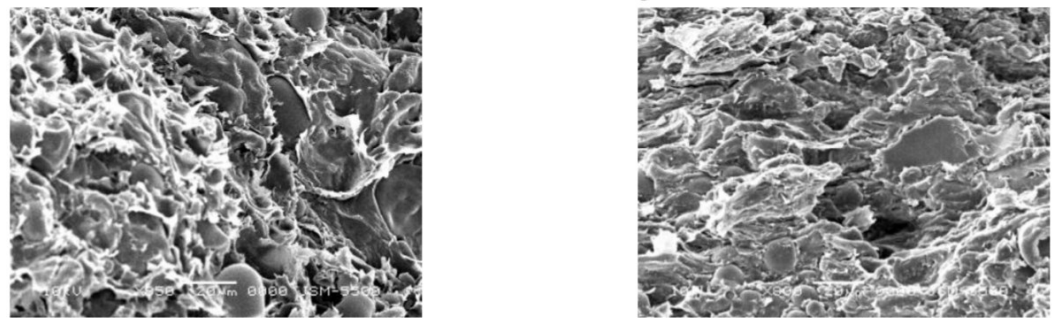

(OFSP flour:Wheat flour:SE = 70:130:40) (OFSP flour:Wheat flour:SE = 115:75:45)

b. After cooking

Figure 4. SEM micrographs of uncooked/cooked noodles (230x magnification)

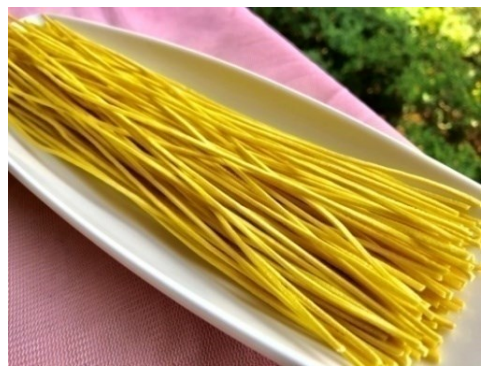

a.

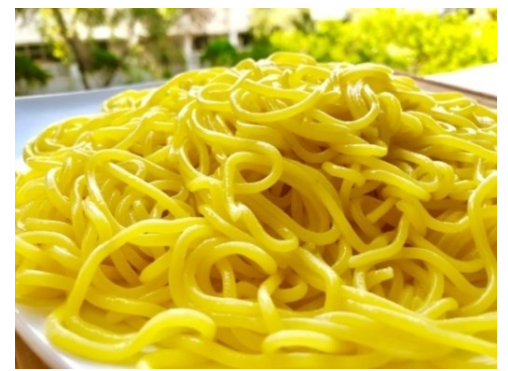

b.

Figure 5. Uncooked (a)/Cooked noodles (b)

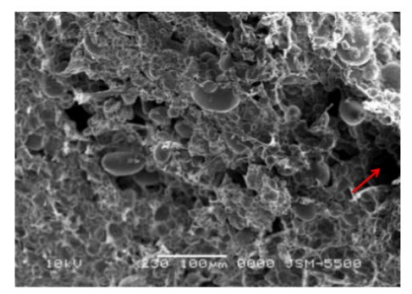

a.

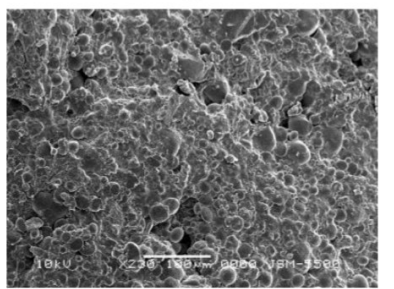

d.

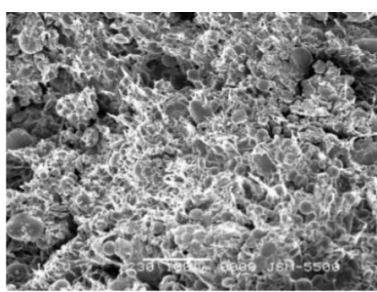

b.

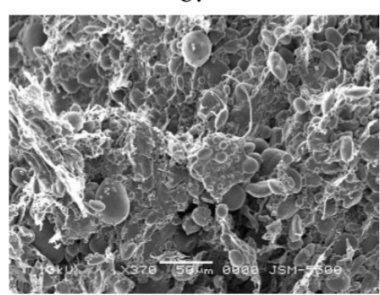

e.

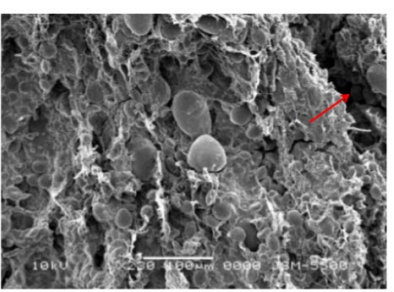

c.

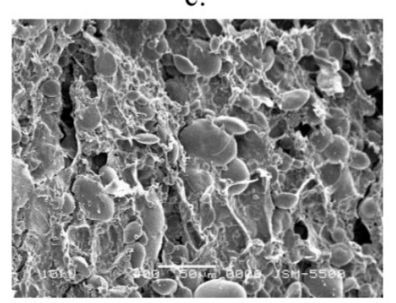

f.

Figure 6. Cross-section of noodles (with different the content of xanthan gum (XG) addition and incubation time) observed with SEM (370x magnification)

Note:

a. XG addition: $1.5 \%+$ Incubation time: 30 mins; b. XG addition: $2 \%+$ Incubation time: 30 mins;

c. $\mathrm{XG}$ addition: $2.5 \%+$ Incubation time: $30 \mathrm{mins}$; $\mathrm{d}$. XG addition: $1.5 \%+$ Incubation time: 45 mins;

e. XG addition: $2 \%+$ Incubation time: 45 mins; f. XG addition: $2.5 \%+$ Incubation time: 45 mins. 
entire volume of the cell (Bordoloi et al., 2012). In overall, semolina showed more favorable impacts on the structural characteristics of OFSP noodles.

\subsection{Effect of xanthan gum and incubation time}

Gums are widely used in starch-based products mainly to improve stability, modify texture and facilitate processing. Among different kinds of gums, xanthan gum is most widely used in food processing (Norton and Foster, 2002). Starch granules tended to completely covered by gluten when the proportion of xanthan gum addition increased to $2.0-2.5 \%$. Gums decreased firmness and cohesiveness of the noodles but increased adhesiveness (Figure 6). This might be attributed to the delayed swelling of granules as well as lesser interaction and association within the granules in the presence of gums.

Dough incubation time is another factor that affects the structure of the noodles. The structure of noodles tended to increase slightly when the incubation time increased from 30 to 45 mins. During resting, several factors may affect dough rheology: relaxation of the stresses introduced during mixing continued hydration of flour components and redistribution of water. It is also possible that alteration of gluten and starch may occur because of enzymatic action. Another possibility is that the sulfhydryl-disulfide interchange continues during dough resting (Dong and Hoseney, 1995).

\section{Conclusion}

The supplementation of OFSP is likely to enhance the nutritional value of noodles. The formulation of OFSP and wheat flour with the ratio of $18.79 \%$ and $28.18 \%$, respectively, can be used to produce the highquality product and was the best among the four formulas (OFSP flour could be replaced up to $40 \%$ in the total weight of wheat flour and OFSP). The content of semolina addition of $10.57 \%$, xanthan gum of $2 \%$ and the incubation time $30 \mathrm{mins}$ were showed to enhance physical properties of noodles. Further research is needed to establish the optimal combination of OFSP flour content and production conditions to obtain nutritionally valuable noodles with optimal physical properties, affordable and acceptable.

\section{Conflict of Interest}

The authors declare no conflict of interest.

\section{References}

Aina, A.J., Falade, K.O., Akingbala, J.O. and Titus, P. (2009). Physicochemical properties of twenty-one Caribbean sweet potato cultivars. International
Journal of Food Science and Technology, 44(9), 1696-1704. https://doi.org/10.1111/j.1365-

2621.2009.01941.x

Alam, M., Rana, Z. and Islam, S. (2016). Comparison of the proximate composition, total carotenoids and total polyphenol content of nine orange-fleshed sweet potato varieties grown in Bangladesh. Foods, 5(3), 64-73. https:// doi.org/10.3390/foods5030064

Association of Official Analytical Chemistry (AOAC) Official methods of analysis. (1980). 13 ${ }^{\text {th }}$ ed. Arlington, VA: Association of Official Analytical Chemists.

Barros, F., Alviola, J.N. and Rooney, L.W. (2010). Comparison of quality of refined and whole wheat tortillas. Journal of Cereal Science, 51(1), 50-56. https://doi.org/10.1016/j.jcs.2009.10.001

Bashir, K.H., Aeri, V. and Masoodi, L. (2012). Physiochemical and sensory characteristics of pasta fortified with chickpea flour and defatted soy flour. Journal of Environmental Science, Toxicology and Food Technology, 1(5), 34-39. https:// doi.org/10.9790/2402-0153439

Bordoloi, A., Kaur, L. and Singh, J. (2012). Parenchyma cell microstructure and textural characteristics of raw and cooked potatoes. Food Chemistry, 133(4), 10921100 .

j.foodchem.2011.11.044

https://doi.org/10.1016/

Bovell-Benjamin, A.C. (2007). Sweet potato: A review of its past, present, and future role in human nutrition. Advances in Food Nutrition Research, 52, 1-59. https://doi.org/10.1016/S1043-4526(06)520017

Cacak-Pietrzak, G., Haber, T., Lewczuk, J. and Madrias, M. (1997). Quality evaluation of selected extra pasta on the Warsaw market. Przegl Zboz MLyn, 41, 2629.

Collado, L.S. and Corke, H. (1997). Properties of starch noodles as affected by sweet potato genotype. Cereal Chemistry, 74(2), 182-187. https://doi.org/10.1094/ CCHEM.1997.74.2.182

Dick, J.W. and Youngs, V.L. (1988). Evaluation of durum wheat, semolina, and pasta in the United States. In Fabriani, G. and Lintas, C. (Eds.) Durum Wheat Chemistry and Technology. St. Paul: AACC Press.

Dong, W. and Hoseney, R.C. (1995). Effects of certain breadmaking oxidants and reducing agents on dough rheological properties. Cereal Chemistry, 72(1), 5863.

Dubois, M., Gilles, K.A., Hamilton, J.K., Rebers, P.T. and Smith, F. (1956). Colorimetric method for 
determination of sugars and related substances. Analytical Chemistry, 28(3), 350-356. https://doi.org/10.1021/ac60111a017

Fikselová, M., Šilhár, S., Mareček, J. and Frančáková, H. (2008). Extraction of carrot (Daucus carota L.) carotenes under different conditions. Czech Journal of Food Sciences, 26(4), 268-274. https:// doi.org/10.17221/9/2008-CJFS

Fu, B.X. (2008). Asian noodles: History, classification, raw materials, and processing. Food Research International, 41(9), 888-902. https:// doi.org/10.1016/j.foodres.2007.11.007

Ginting, E. and Yulifianti, R. (2015). Characteristics of noodle prepared from orange-fleshed sweet potato, and domestic wheat flour. Procedia Food Science, 3, 289-302.

https://doi.org/10.1016/

j.profoo.2015.01.032

Gorinstein, S., Pawelzik, E., Delgado-Licon, E., Yamamoto, K., Kobayashi, S., Taniguchi, H. and Trakhtenberg, S. (2004). Use of scanning electron microscopy to indicate the similarities and differences in pseudocereal and cereal proteins. International Journal of Food Science and Technology, 39(2), 183-189.

General Statistics Office (GSO). (2009). Retrieved from GSO website: https://www.gso.gov.vn/Default.aspx? tabid $=217$

Haskell, M.J., Jamil, K.M., Hassan, F., Peerson, J.M., Hossain, M.I., Fuchs, G.J. and Brown, K.H. (2004). Daily consumption of Indian spinach (Basella alba) or sweet potatoes has a positive effect on total-body vitamin A stores in Bangladeshi men. The American Journal of Clinical Nutrition, 80(3), 705-714. https:// doi.org/10.1093/ajen/80.3.705

Jahan, M.A. and Siddique, M.A.R. (2001). Studies on growth, yield and storage of sweet potato as influenced by variety and time of harvest. Mymensingh, Bangladesh: Bangladesh Agricultural University, MSc. Thesis.

Kamolchote, S., Seng, T.T., González, J. and Hou, G.G. (2010). Quality assurance programs for Instant Noodle production. In Hou, G.G (Eds). Asian Noodles: Science, Technology, and Processing, p. 363-392. UK: Wiley Online LIbrary. https:// doi.org/10.1002/9780470634370.ch15

Kim, Y.S., Wiesenborn, D.P., Lorenzen, J.H. and Berglund, P. (1996). Suitability of edible bean and potato starches for starch noodles. Cereal Chemistry, 73(3), 302-308.

Krishnan, J.G., Menon, R., Padmaja, G., Sajeev, M.S. and Moorthy, S.N. (2012). Evaluation of nutritional and physico-mechanical characteristics of dietary fiber-enriched sweet potato pasta. European Food Research and Technology, 234(3), 467-476. https:// doi.org/10.1007/s00217-011-1657-8

Manthey, F.A., Lee, R.E. and Kegode, R.B. (2000). Quality of spaghetti containing ground flaxseed. In Proceedings of the 58th Flax Institute of the US, p. 92-99. Fargo, North Dakota, United States: Flax Institutes of the United States.

McCseady, R.M. (1970). Determination of starch and dextrin in methods of Food Analysis. $2^{\text {nd }}$ ed., $p$. D.225-227. London, UK: Academic Press.

Mitra, S. (2012). Nutritional status of Orange-Fleshed Sweet Potatoes in alleviating vitamin A malnutrition through a food-based approach. Journal of Nutrition Food Science, 2(8), 160-164. https:// doi.org/10.4172/2155-9600.1000160

Norton I.T. and Foster T.J. (2002). Hydrocolloids in real food systems. In Williams P.A., Phillips, G.O. (Eds). Gums and stabilizers for the food industry, p. 187-200. Cambridge: The Royal Society of Chemistry. https://doi.org/10.1039/978184755101600187

Osundahunsi, O.F., Fagbemi, T.N., Kesselman, E. and Shimoni, E. (2003). Comparison of the physicochemical properties and pasting characteristics of flour and starch from red and white sweet potato cultivars. Journal of Agricultural and Food Chemistry, 51(8), 2232-2236. https:// doi.org/10.1021/jf0260139

Penella, J.S., Collar, C. and Haros, M. (2008). Effect of wheat bran and enzyme addition on dough functional performance and phytic acid levels in bread. Journal of Cereal Science, 48(3), 715-721. https:// doi.org/10.1016/j.jcs.2008.03.006

Rahman, M.H., Alam Patwary, M.M., Barua, H., Hossain, M. and Nahar, S. (2013). Evaluation of orange fleshed sweet potato (Ipomoea batatas L.) genotypes for higher yield and quality. The Agriculturists, 11(2), 21-27. https://doi.org/10.3329/ agric.v11i2.17483

Roy, S., Banerjee, A., Tarafdar, J. and Mitra, S. (2012). Tuber quality assessment of orange-fleshed sweet potato (Ipomoea batatas) cultivars and their genetic relatedness as revealed by SDS-PAGE of tuber proteins. Indian Journal of Agricultural Sciences, 82 (6), 482-488

Salem, H.B., Abdouli, H., Nefzaoui, A., El-Mastouri, A. and Salem, L.B. (2005).Nutritive value, behaviour, and growth of Barbarine lambs fed on old man saltbush (Atriplexnum mularia L.) and supplemented or not with barley grains or spineless cactus (Opuntiaficus-indica f. inermis) pads. Small 
Ruminant Research, 59(2-3), 229-237. https:// doi.org/10.1016/j.smallrumres.2005.05.010

Senthil, A., Ravi, R., Bhat, K.K. and Seethalakshmi, M.K. (2002). Studies on the quality of fried snacks based on blends of wheat flour and soya flour. Food Quality and Preference, 13(5), 267-273. https:// doi.org/10.1016/S0950-3293(02)00023-X

Singh, N., Singh, J. and Singh Sodhi, N. (2002). Morphological, thermal, rheological and noodlemaking properties of potato and corn starch. Journal of the Science of Food and Agriculture, 82(12), 1376 -1383. https://doi.org/10.1002/jsfa.1194

Sozer, N., Dalgic, A.C. and Kaya, A. (2007). Thermal, textural and cooking properties of spaghetti enriched with resistant starch. Journal of Food Engineering, 81(2), 476-484. https:// doi.org/10.1016/j.jfoodeng.2006.11.026

Taneya, M.L.J., Biswas, M.M.H. and Ud-Din, M.S. (2014). The studies on the preparation of instant noodles from wheat flour supplementing with sweet potato flour. Journal of the Bangladesh Agricultural University, 12, 135-142. https://doi.org/10.1016/ j.jfoodeng.2006.11.026

Teye, E., Asare, A.P., Amoah, R.S. and Tetteh, J.P. (2011). Determination of the dry matter content of cassava (Manihotes culenta, Crantz) tubers using specific gravity method. ARPN Journal of Agricultural and Biological Science, 6(11), 23-28.

Tudorica, C.M., Kuri, V. and Brennan, C.S. (2002). Nutritional and physicochemical characteristics of dietary fiber enriched pasta. Journal of Agricultural and Food Chemistry, 50(2), 347-356. https:// doi.org/10.1021/jf0106953

Utomo, J.S. and Yulifianti, R. (2012). Characteristics of noodle prepared from blended of wheat flour and purple-fleshed sweet potato. In Widjono A., Hermanto, Nugrahaeni N., Rahmianna A. A., Suharsono, Rozi F., Ginting E., Taufiq A., Harsono A., Prayogo Y. and Yusnawan E. (Eds.) Proceedings of National Seminar on The Results of Legumes and Tuber Crops Research in 2011. Malang, 15 November 2011., p. 768-775. Bogor: Indonesian Research and Development Center for Food Crops. [In Bahasa Indonesia].

Wang, H. and Ratnayake, W.S. (2016). Great Northern Bean Could Improve the Nutritional Value of Instant Noodles. Cereal Chemistry, 93(2), 156-161. https:// doi.org/10.1094/CCHEM-06-15-0133-R 